\title{
Chemistry Education in Kosovo: Issues, Challenges and Time for Action
}

\author{
FATLUMe Berisha ${ }^{1}$
}

$\approx$ Although several reforms have shifted the direction of education, a debate on the strengths and limitations of science education in Kosovo has not yet been initiated. The present article analyses the development of chemistry education in Kosovo and encourages questions that could shape science education practices in general. In particular, the article analyses the pre-university chemistry curriculum in Kosovo over the years, as well as examining chemistry teacher education programmes. The analysis is based on descriptive research of data and document analysis. The multidimensional analysis of the issues and challenges of chemistry education will provide recommendations for future research on chemistry education and chemistry teaching practices in order to make chemistry education and the pre-university chemistry curriculum relevant to the context of Kosovo. As pre-university education curricula, especially the curriculum for the natural sciences, and the preparation of both pre-service and inservice teachers in Kosovo are considered challenging, a firm conclusion for actions has not been reached. Nevertheless, the article seeks to spark a debate in the field.

Keywords: chemistry education, chemistry curriculum, chemistry teacher education, pre-service chemistry education 


\title{
Kemijsko izobraževanje na Kosovu: vprašanja, izzivi in čas za ukrepanje
}

\author{
FATLUME BERISHA
}

$\propto$ Čeprav je vrsta reform že spremenila smer izobraževanja, se razprava o prednostih in omejitvah naravoslovnega izobraževanja še ni začela. Prispevek analizira razvoj kemijskega izobraževanja na Kosovu in postavlja vprašanja, ki bi lahko na splošno oblikovala naravoslovno izobraževalno prakso. Natančneje, prispevek analizira preduniverzitetni kurikulum na Kosovu v zadnjih nekaj letih pa tudi študijske programe za izobraževanje učiteljev kemije. Raziskava temelji na deskriptivni analizi podatkov in analizi dokumentov. Multidimenzionalna analiza vprašanj in izzivov kemijskega izobraževanja bo omogočila oblikovanje priporočil za prihodnje raziskave na področju kemijskega izobraževanja in prakse poučevanja kemije $z$ namenom narediti kemijsko izobraževanje in preduniverzitetni kurikulum relevanten za kosovski kontekst. Ker se učni načrti preduniverzitetnega izobraževanja, zlasti učni načrti za naravoslovje in učni načrti študijskih programov za izobraževanje učiteljev ter za programe izpopolnjevanja učiteljev na Kosovu, štejejo za zahtevne, nekih zavezujočih sklepov za ukrepe še ni bilo doseženih. Kljub temu pa je namen tega prispevka sprožitev razprave na tem področju.

Ključne besede: kemijsko izobraževanje, kemijski kurikulum, izobraževanje učiteljev kemije, študijski programi za izobraževanje učiteljev kemije 


\section{Introduction}

According to the latest European Commission report (2019), education quality in Kosovo remains a challenge at all levels. Kosovo is at an early stage of any kind of educational, cultural, scientific and research preparation. There has been no progress in the past years and there is still a need to significantly improve the quality of education and fields of innovation. A lack of qualified teaching staff, teaching materials and supplies, combined with an underdeveloped student evaluation system, undermines the implementation of curriculum reform. Kosovo's teacher training system needs to be strengthened to improve the quality of both pre-university and university level education. It has an education system framework that is still unable to provide young people with the knowledge and skills required to meet labour market demands (UNDP, 2016). Pupovci (2002) found that the traditional education framework was based on teacher-centred learning and memorisation, and this obsolete practice still continues in many cases. As a result, Kosovo is ranked among the lowest of all participating nations in the PISA science test (OECD, 2016). Such concerning data indicate that science teaching in Kosovo is insufficiently effective and may result from the poor performance of inquiry-based teaching and learning and/or active learning.

In an effort to improve the quality of education in Kosovo and harmonise with developed countries, the Ministry of Education, Science and Technology (MEST) approved the New Kosovo Curriculum Framework (KCF) in 2011. This framework is supposed to facilitate a shift from objective and content-based methodologies to contemporary teaching and learning methodologies based on student outcomes and the development of student competencies (MEST, 2016). Furthermore, in 2012, MEST made the choice to reform study programmes for the qualification of subject teachers according to the successive model. Thus, all teachers should complete three years of academic studies for the corresponding subjects in appropriate academic programmes at the bachelor's level and two years at the master's level at the Faculty of Education, where they have specialised instruction in pedagogy content knowledge courses, general pedagogical knowledge and teaching practices. These programmes were offered for the first time in the 2016/2017 academic year. Science educators in Kosovo are therefore expected to make use of the opportunity to enhance teaching practices and student quality outcomes and use the reform to overcome longstanding obstacles. Teaching science through inquiry, argumentation, project-based learning and problem-based learning, as well as using formative assessment purposes and making learning relevant to students' daily lives, is the main goal of the curriculum reforms in Kosovo (MEST, 2016a). 
The main objective of the present article is to reflect briefly on the education system, focusing on the current situation, issues and challenges of science education, in particular chemistry education, in Kosovo. Through relevant literature reviews and analysis of the past education system and curriculum, the author would like to identify and understand the obstacles and issues that the current education system faces today. Guidelines that could encourage and meaningfully contribute to future research for the improvement of chemistry education in Kosovo will be discussed. The article should also stimulate debate on the strengths and limitations of chemistry education and science teaching and learning, as well as catalysing further discussion in order to help create a proper system that fits the population and their goals for the future of science development, resulting in economic growth. It should be noted that, due to the lack of previous research on this matter, the article covers a wide spectrum of analysis and it is difficult to support conclusive recommendations. Furthermore, chemistry teaching in compliance with European norms will be discussed as measures needed for the development and improvement of science teaching and learning in the Kosovo education system.

\section{Theoretical Framework}

"Europe Needs More Scientists" and "Towards a Sustainable Europe by 2030 " are the headings of European Commission reports on increasing human resources for science and technology in Europe and moving it towards a sustainable future (European Commission, 2004, 2019). The declining interest in studying science is one of Europe's biggest concerns of the $21^{\text {st }}$ century. Osborne and Dillon (2008) state that the current curricula and educational practices around Europe are failing to engage young generations in the study of science. Numerous studies worldwide have examined the declining interest in science education in general (European Commission, 2004; Haste, 2004; OECD, 2006; Osborne, Simon, \& Collins, 2003; Osborne, 2007; Osborne \& Dillon, 2008; Sjoberg \& Schreiner, 2005). According to Rocard et al., (2007) the lack of interest in science studies is due to the way science is taught in schools. This issue should therefore be the main focus of improvement in future science education.

Taber (2017) explains that science education, as a research field, is "concerned with developing knowledge about the learning of science, and the teaching of science", while Cooper and Stowe (2018) give an excellent review on chemistry education, in which they state that chemistry education research is mainly "concerned with teaching and learning in chemistry, investigated through a variety of qualitative and quantitative methods". Researchers 
in chemistry education are exploring a wide variety of areas of teaching and learning chemistry, including the processes by which learners build knowledge and understand chemistry, as well as the obstacles that hinder construction. Chemistry education research concerns the development of tools that measure knowledge, attitudes, identity and other affecting constructs, such as how student learning can be integrated into curriculum design and the impact of curricular revolutions.

According to Shulman (1987), one of the core competencies that all preservice science teachers should build in order to achieve any reform objectives in their schools and classrooms is an understanding of pedagogical content knowledge (PCK), which has been proven to be a challenging task for science teacher educators. In addition, Shulman (1986) states that, although PCK is essential to teachers' knowledge, content knowledge $(\mathrm{CK})$ is a requirement for the development of PCK. Bucat (2004) explains that PCK refers to an understanding of the teaching and learning of specific subjects, taking into account the specific learning requirements essential in that subject matter, whereas $\mathrm{CK}$ refers to one's knowledge of the subject, and pedagogical knowledge (PK) refers to one's knowledge of teaching and learning independent of the subject matter. Every chemistry teacher has a distinctive understanding of chemistry, but they all share the same role as teachers: repackaging and representing their knowledge of chemistry in a way that ensures the students' understanding of the subject. It is very important that teachers of chemistry not only know the subject matter, but also know the subject in terms of knowledge transfer through teaching and learning (Bucat, 2004).

Ensuring that all young people are taught by highly qualified educators is viewed as a key target for overall training frameworks for teacher preparation. The European Commission's Strategic Framework for Education and Training 2020 (European Commission/EACEA/Eurydice, 2013) points out that high-quality "pre-primary, primary, secondary, higher and vocational education and training" is central to Europe's success. Similarly, for Kosovo, the newest country of Europe, the quality of teacher preparation is essential to the quality of teaching. Teacher preparation in Kosovo should provide balanced and consistent teaching practices with proper access to training and professional development for the improvement of CK, PCK, teaching skills and teaching practices in schools.

Desk literature research on science and chemistry education, along with research on chemistry teacher preparation, and its reforms in Kosovo over the years have failed to yield reliable information. To date, there is no documented research of any kind on science and/or chemistry education in Kosovo. What 
follows is an attempt to offer information on the current situation of the science and/or chemistry education practices and research in Kosovo.

\section{The Education System and Chemistry Education: The Pre-University Chemistry Curriculum in Kosovo}

Several reforms have shifted the direction of education in Kosovo over the years. Consistent information on the general education system in Kosovo before the war of 1999 is hard to find and is not the focus of the present paper. For more information regarding the education system in Kosovo before 1999, please refer to the work of Pupovci (2000), Bache and Tayor (2003), Baliqi (2010) and Bicaj and Berisha (2013).

Immediately after the war of 1999, the United Nations (UN) took over the responsibility to rebuild Kosovo (Vula \& Saqipi, 2009). The process of the normalisation of education was assisted by many international organisations. Until 200o, education in Kosovo fought for survival and, as a result, did not inherit any set goals and objectives for the persisting system of education in Kosovo. During the 2000-2001 academic year, many legal and professional preparations were made to generate a new system of education in Kosovo. Education standards, curricula, teacher training, special needs education and vocational education, as well as a statute for higher education and university reforms in alignment with the Bologna Process, were initiated (Vula \& Saqipi, 2009).

In March 2002, the Ministry of Education, Science and Technology (MEST) was established in Kosovo, followed by the establishment of the Faculty of Education (FE) at the University of Prishtina (UP) that same year. The MEST took over the education system with the intention of shifting education in Kosovo from the emergency phase to the consolidation phase, and with the goal of achieving European Union (EU) educational processes and trends. Their vision was to build Kosovo into "a democratic and knowledge society", integrated into Europe, and to establish long-term and sustainable social and economic development (MEST, 2007). The education system was the subject of reforms at all levels of education in an attempt to establish a system similar to that of the EU, with $5+4+3$ for primary, lower secondary and upper secondary school education, and the Bologna Process for higher education.

From 2002 to 2017 , the curriculum for pre-university education offered a chemistry course from lower secondary school in grade 7 to upper secondary school grade 12 (Figure 1). In elementary primary education, a science education course was offered at grades 3, 4 and 5, for one hour per week. In lower secondary education in Kosovo, chemistry was offered two hours per week in 
grades 7,8 and 9. In upper secondary education, natural science gymnasium (grammar) schools (natural sciences, mathematical, general) offered chemistry in grades 10, 11 and 12, with a minimum of two and a maximum of three hours per week (Figure 1). Medical vocational schools offered one hour per week of chemistry for four years, and chemical technology schools offered two hours per week in grades 10 and 11. Other upper secondary schools, such as social sciences gymnasiums (social science and linguistics) and mechanical, agricultural and metallurgy vocational schools offered one year of chemistry during upper secondary education (at least one academic hour per week). On the other hand, economics, engineering, graphics, hotelier/tourism and geodesy/construction vocational schools of upper secondary education did not offer any chemistry courses. In general, lower and upper secondary education in Kosovo offered a respectable number of chemistry hours per week.

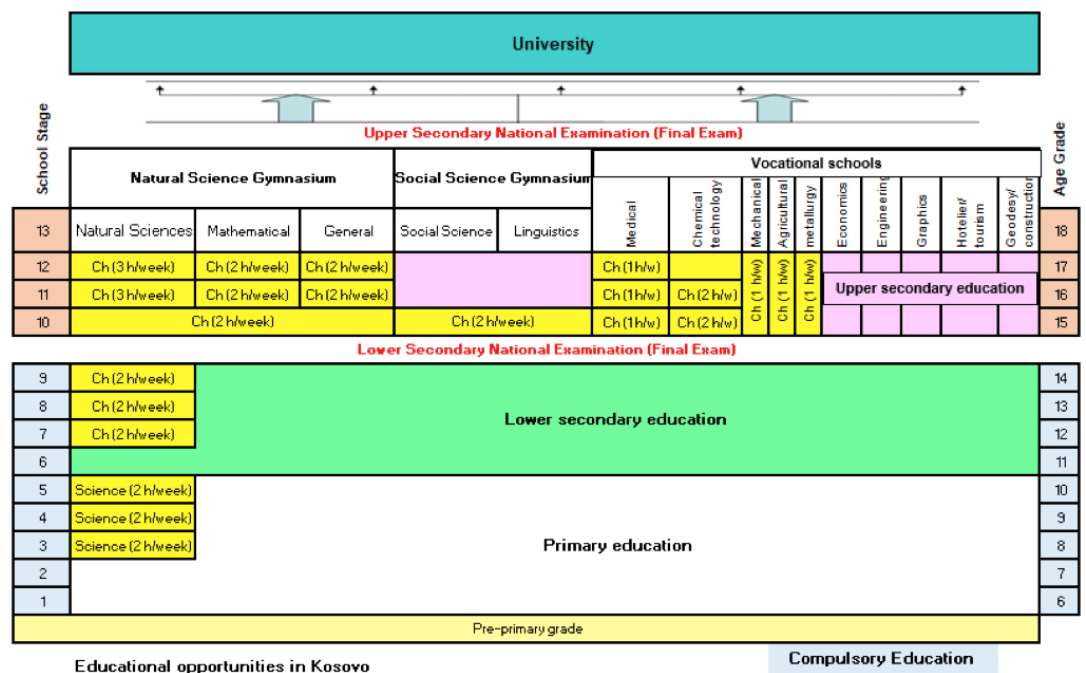

Figure 1. Education pathway and chemistry hours offered by the education system in Kosovo (2002-2017).

With the new KCF implementation as of 2017, there were no significant changes to the number of chemistry hours offered per week. The only significant change was the introduction of science courses starting in the first and second grades in primary education with one hour per week and continuing through the third, fourth and fifth grades with two hours per week (Figure 2). The curriculum for technical/vocational schools has not yet been drafted. 


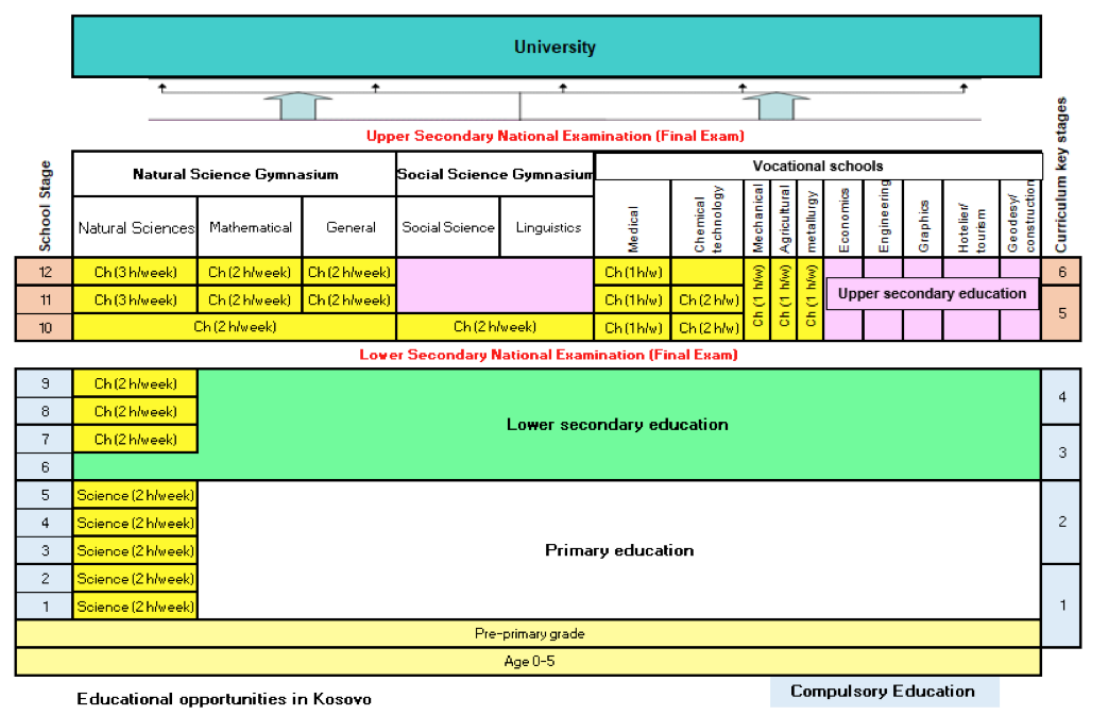

Figure 2. Education pathway and chemistry hours offered by the education system in Kosovo (2017-present).

The new KCF aims to shift central-based teaching and learning towards the competency-based approach. It seeks the development and implementation of learner-centred teaching and learning, as well as inclusion, integrated teaching and learning, flexibility and mobility, in addition to transparency and accountability. The key learning competencies envisioned for the pre-university education system in Kosovo are (MEST, 2016a): communication and expression, thinking, learning, life, work and environmental learning, personal and civic competences. The core curricula (MEST, 2016b, 2016c) provide detailed learning competencies for all six key stages of the pre-university education system.

According to the new KCF (MEST, 2016a), primary education (key stages 1 and 2) nurtures basic learning habits and cognitive and social-emotional development, with special attention devoted to personality development and building a positive attitude towards learning. Lower secondary education (key stages 3 and 4) offers new challenges towards cognitive, physical, personal, social and ethical development. The curriculum for lower secondary education is enriched with broad exposure to learning experiences with the goal of helping students to identify their preferences and areas of special interest. Upper secondary education (key stages 5 and 6) aims for a wider, deeper and more specialised process of learning. Depending on the route, the upper secondary education curriculum orients students toward gymnasium school (natural sciences, mathematical, general, social sciences and linguistics gymnasium), technical/ 
vocational qualifications and/or the labour market as qualified workers, and is supposed to equip students with lifelong learning skills (MEST, 2016a).

The core curriculum of science for the three pre-university levels of education aims to achieve knowledge, understanding, habits, skills, attitudes and values enabling students to understand the concepts, theories and laws of nature, as well as its fundamental phenomena. The aim of the science curriculum is to contribute to the general growth and development of society, helping to increase the level of technology use and boost economic development, thus enhancing the quality of human life and maintaining health, the living environment and wellbeing. Students should develop a curiosity for the natural environment of scientific research and human-induced change; they should embrace the scientific skills of beginners, acquiring the concepts, tools and procedures required to draw conclusions from data analysis and to present and evaluate results; and they should develop problem-solving skills by using tools when undertaking individual and teamwork tasks. In this way, students will develop critical thinking and will be trained to identify problems, ask questions, formulate hypotheses and draw conclusions based on arguments, as well as to follow the steps of scientific methodology (MEST, 2016a).

In key stages 1 and 2, students learn about the natural and man-made environment, and research methods for studying processes and natural phenomena. In key stages 3 and 4, lessons in physics, chemistry and biology are taught, thus achieving an integrated interdisciplinary approach to teaching sciences. Whereas in key stages 5 and 6, sciences are taught in general upper secondary schools as the separate subjects of physics, biology, chemistry and astronomy, the teaching of technical/vocational sciences is still under development (MEST, 2016a). In the curriculum of lower secondary education, key stages 3 and 4 describe the teaching of sciences as integrated practices. In practice, however, the science courses physics, chemistry and biology are taught as separate courses. According to the lower and upper secondary core curriculum (MEST, 2016b, 2016c), the natural sciences will facilitate the integrated development of competencies aimed at helping students in social, health and economic terms related to various issues at the national and global levels. The general concepts of science in lower and upper secondary education consist of: 1) matter, properties and transformations, 2) physical processes, 3) the living world, and 4) the Earth, the environment and the universe.

The number of hours of chemistry taught in lower and upper secondary education has not changed compared to the previous curriculum. However, an increase in the content and materials that have to be taught during a chemistry course has been noted, but this is not accompanied by an increase in the time 
allocated for chemistry teaching. Instead, the latter has been fitted into the preexisting timeframe.

The new KCF teaching goals and objectives have shifted from traditional education to $21^{\text {st }}$ century skills-based education focused on competences, which demands changes to the way science is taught in schools. The teaching of science content has shifted towards a constructive approach and inquiry-based teaching and learning. Scientific literacy and science processing abilities and skills have been moved to the centre of the curriculum, demanding pre-service and in-service science teacher training programmes to promote inquiry-based science teaching and learning. The current curriculum requires that science teachers understand inquiry abilities and skills, and that they use investigation/inquiry methods rather than direct instructions in their schools to educate the future leaders of the $21^{\text {st }}$ century. The curriculum builds on school-based, competency-based, student-centred, research-based, integrated and community-oriented practices.

\section{Chemistry Teacher Education in Kosovo}

Until 2002, lower secondary chemistry teachers in Kosovo attended higher pedagogical schools, which offered a two-year study programme to qualify graduates to teach $7^{\text {th }}$ and $8^{\text {th }}$ grade chemistry courses. With the establishment of the Faculty of Education in 2002, the latter took over responsibility for teacher preparation, including that of chemistry teachers for lower secondary education $\left(7^{\text {th }}, 8^{\text {th }}\right.$ and $9^{\text {th }}$ grade), offering four-year bachelor studies with 240 ECTS credits. Upper secondary chemistry teachers were prepared at the Department of Chemistry of the Faculty of Natural Science and Mathematics (FNSM) at the University of Prishtina, which offered a four-year programme (Vula, Saqipi, Kraja, \& Mita, 2012).

Teacher preparation for lower secondary education offered two subject degrees: Chemistry/Biology and Chemistry/Physics. Until the 2011/2012 academic year, CK and PCK courses were offered equally for the two subjects, in addition to general PK and school practices. Due to limited CK courses on the two major subjects, pre-service chemistry teachers attending the Faculty of Education lacked CK compared to pre-service chemistry teachers attending the Department of Chemistry at the FNSM, while the latter lacked PCK and general PK competencies. The subject teacher preparation gaps created due to the lack of CK, PCK and general PK were evident and were discussed among education stakeholders, who called for immediate reforms. According to Vula et al. (2012), universities faced countless issues in pre-service teacher 
education, primarily in terms of curricula, teaching methodology, pedagogy, teaching practice and research. Since the Kosovo education system lacked national standards, different curricula offered by different universities have significant pedagogical differences.

In the 2009/2010 academic year, the Accreditation Agency for academic programmes requested that the University of Prishtina and MEST review the model and quality of teacher training and preparation programmes. This was also reflected in the European Commission Progress Reports 2010-2011 (European Commission, 2010, 2011), which recommended reform of teacher training. Eventually, in 2012, MEST decided to reform the preparation of subject teachers according to the consecutive $3+2$ model, whereby prospective teachers should complete three years of academic subject/content bachelor studies at the academic units and two years at the master's level at the Faculty of Education with general and pedagogical content knowledge courses offered. The reform advocated by MEST for pre-university teacher preparation was in line with the KCF reforms. The latter has also established coherence in the system of teacher preparation by ensuring that, besides CK courses (180 ECTS), each new teacher also takes appropriate general PK and PCK courses, as well as gaining practice teaching experience in schools (120 ECTS). As a result of the reforms undertaken, the current chemistry teacher preparation programme aims to prepare future chemistry teachers who are competent both in CK and PCK, as well as in general PK and teaching practices. CK is supposed to be refined at the Department of Chemistry of the FNSM through a variety of subject matter courses in a three-year study programme, while PCK is further developed at the Faculty of Education through a variety of educational courses.

According to the European reforms of chemistry education, chemistry students pursuing a bachelor's degree are, upon completion, expected to have developed a range of different abilities, skills and competencies, as outlined by Pinto (2010). The Bologna Process has made chemistry education teaching and learning an active process by using hands-on activities, cooperative learning and technology, and by engaging in problem-based learning, project-based learning, inquiry-based learning, case studies and the environment, as well as other learning strategies that were not present before. Within the Bologna Process, chemistry education has adopted modern pedagogical methodologies taking into consideration all of the competencies (specific, generic and transferable) and skills as a basis of the learning outcomes (Pinto, 2010).

The goal of the chemistry teacher education programme at the Faculty of Education is to equip pre-service chemistry teachers with competencies in both the CK and PCK of chemistry with the ability to teach chemistry. In order 
to train future chemistry teachers with these competencies, the current practices of chemistry teacher education programmes provide two branches of education and two levels of education: the bachelor's level, where the students obtain CK courses, and the master's level, where they acquire PCK and general PK through educational courses and practice teaching. The general belief behind this type of educational design is that after taking these courses pre-service teachers will be able to integrate the separate knowledge of pedagogy and subject matter and implement this knowledge in classroom teaching.

\section{Issues and Challenges: Time for Action}

\section{Obstacles and issues that the current education system faces today}

Due to a lack of research on chemistry education, several potential issues and challenges can be raised regarding the future of chemistry education in Kosovo, mainly based on a literature review, the chemistry curriculum and chemistry teacher preparation programmes.

In his study on making chemistry teaching relevant, Holbrook (2005) summarises the results of several studies on the issues of chemistry teaching. The many issues encountered include the fact that chemistry teaching is unpopular and irrelevant to students, that there is a failure to promote higherorder cognitive skills, that gaps are generated between what students want to learn and what teachers teach, and that chemistry teaching is not changing because teachers are afraid of change and need professional development. Similarly, Rocard et al. (2007) claim that science education problems and issues are a reflection of the way science is taught in schools.

This supports the finding of a previous study conducted by Berisha, (2013), which stated that students who entered the Faculty of Education in Kosovo during the 2009/2010 academic year with the intention of becoming chemistry teachers were not prepared for the study of chemistry education at the university level. The indicated study screened first-year students $(n=176)$ on five chemistry basic knowledge questions. Only $0.6 \%$ of the students answered all five questions correctly, 2.8\% answered four questions correctly, 8.5\% provided three correct answers, $18.2 \%$ provided two correct answers, and $27.3 \%$ provided one correct answer, while $42.6 \%$ did not give an answer or the answer was not correct. On closer examination of their chemistry background based on their upper secondary school, it was found that $46.6 \%$ of the students came from gymnasium schools (natural science, mathematics and general) and 6.8\% 
came from a medical vocational school where they had attended chemistry courses every year of their upper secondary education. The rest of the students came from other technical/vocational schools with no chemistry education or at least one year of chemistry courses taken during upper secondary education. Given that more than $50 \%$ of the students had taken chemistry courses in more than two years of high school, the test results were discouraging. The results suggest that chemistry instruction at lower and upper secondary schools in Kosovo is unpopular or irrelevant to students, or that it lacks relevance to chemistry teaching. Furthermore, this finding reflects a lack of interest among students with good results in pre-university studies in becoming teachers, and indicates that the criteria for pre-service teacher selection are not appropriate. Additionally, the teaching of chemistry by in-service teachers often inadequately achieves chemistry learning goals.

The 2015 results of PISA, a test mainly focused on science, listed Kosovo as the third country from the bottom, way below the international average, indicating once more the importance of the emerging science education reforms. The new curriculum reform of the education system in Kosovo, and of chemistry education in particular, advocates competencies that reflect the current developmental needs of the country. However, the reform demands school environment changes and chemistry teacher professional development, as well as the necessary support for quality assurance and capacity building.

A great deal of research has focused on the pre-service and in-service chemistry CK of teachers. The results indicate that their CK is limited and fragmented, and that they lack an understanding of chemistry concepts, which plays an important role in the development of chemistry education (Calik \& Ayas, 2005; Cheung, 2009; De Jong, Veal, \& Van Driel, 2002; Kind, 2014). This calls not only for improvements in PK and PCK, but also for greater emphasis on CK professional development, which, according to Shulman (1986), is a prerequisite for developing PCK. Studies show that PK had become dominant over CK in trying to advance educational theories, similar to pure subject research that tries to advance their theories (Shulman, 1986, 1987). However, these advances in theory should be used to reflect upon and improve the practices of the discipline through applied subject research, instead of advancing only theoretical knowledge of pedagogical practices (Bucat, 2004).

Thus far, international organisation support has focused mostly on providing general PK training, with little or no training in CK and PCK offered to in-service chemistry teachers practising chemistry in lower and upper secondary schools. It is expected that the lack of CK and PCK will diminish with the current reforms of chemistry teacher preparation programmes in Kosovo. 
Prospective teachers of chemistry have enough technical content and pedagogical content courses available, and they should be able to integrate and/or separate pedagogical and content chemistry issues in the classrooms in the future. They are also expected to be skilled in articulating teaching practices in the classroom, as they do have "classroom practice teaching" training to complete throughout their studies. Furthermore, immediate measures should be taken towards the continual professional development of in-service chemistry teachers. According to an EU project report conducted by the Kosovo Education and Employment Network (KEEN, 2019), it is MEST's responsibility to prioritise professional development courses offered based on teachers' needs, not donor priorities, as has been done previously.

Chemistry education in Kosovo should focus on developing programmes for the professional development of chemistry teachers that effectively strengthen $\mathrm{CK}$ and PCK, and improve the quality of teaching by encouraging applied research practices. The future of chemistry education depends heavily on the improvement of chemistry teacher preparation in Kosovo, as well as on the training methods used for teacher training. The implementation of the new science curriculum, in particular the chemistry curriculum, may give rise to a number of issues, such as an appropriate classroom teaching environment, laboratory equipment for daily activities, ample textbooks, and trained teachers to implement such activities, as well as many other issues that cannot be solved quickly.

Changing the curriculum is not enough to improve and bring meaningful advancements to chemistry education (Bodner, 1992). In the past decade, intensive efforts have been undertaken with regard to pure chemistry research practices in Kosovo, but chemistry education research has been left aside. Chemistry education research is crying out for studies that test and document qualitative and quantitative data, research the CK and PCK of pre-service and in-service chemistry teachers and examine chemistry content in the classroom. Inter alia, there is a need for applied research studying how chemistry teachers practise chemistry in classrooms and how students learn chemistry.

Another dilemma is that there is no difference reflected in the way lower secondary and upper secondary subject teachers are prepared. A basic assumption is that chemistry teachers are prepared specifically and broadly for teaching chemistry, both at lower secondary and upper secondary schools. Due to the lack of research on chemistry teacher practices in Kosovo, this remains a grey area, thus creating the assumption that there is a need for a distinctive programme requiring separate specialised preparation of teachers for lower and upper secondary teaching. 
An analysis of the curriculum reveals the strengths and weaknesses of existing practices of chemistry education. It also creates opportunities to find and analyse threats to future improvements. The science curriculum in lower secondary education stresses the interdisciplinary nature of teaching. This means that university level programmes should include study programmes for interdisciplinary teaching, such as STEM (Science, Technology, Engineering and Math) majors, that will further prepare teachers to teach the lower secondary integrated science curriculum. Such study programmes should consider the consecutive nature of science courses and the interrelationships between the different science courses. In particular, they should provide prospective teachers of integrated sciences with an understanding of the multiple angles of science.

Developing the abilities and competencies of future chemistry teachers and science educators will positively influence the contributions to the development of the country that science will make. The latest education system reforms in Kosovo aim to fulfil these norms with the harmonisation of the education system with most European countries. However, as the reforms to chemistry teacher preparation in Kosovo are new, their implementation having commenced only in the $2016 / 2017$ academic year, it is too early to judge the quality of the reform.

\section{Time for Action}

In this emerging world of innovations and global warming, the current teacher preparation programmes focusing on the scientific teaching of subjects is limiting teachers' understanding and practice of interdisciplinary teaching. This is a major concern and an objection that could be raised regarding the teaching of subject courses, particularly the way chemistry is taught in Kosovar schools. If teachers have been educated in a system of subject-specific teaching, then their teaching will be the same as they have been taught. As a result, teachers often fail to conceptualise science and make it interdisciplinary. The emphasis on conceptual understanding of student learning and the relevance of science in daily lives has been discussed by several studies (De Jong, 2008; Holbrook, 2005; Mahaffy, 2004), which state that knowledge of concepts themselves, such as atomic structure or chemical bonding, tends to be emphasised more by teachers, rather than daily-life topics, such as improving air quality for our health, which is potentially a much more relevant starting point to teach. The findings are also in line with Osborne and Dillon's (2008) concerns that science curricula in Europe and other regions have failed to respond to the rapid 
changes to student needs. A new vision of science education issues is therefore needed immediately. Science teacher preparation, especially chemistry teacher preparation, and in-service teacher training programmes in Kosovo have to reflect upon the way chemistry is being taught in schools and respond by adapting changes to student needs.

Chemistry is not a static subject. A stunning growth of knowledge of the field has taken place, which leads to an increase in the quantity of material to be taught (Sheppard \& Robbins, 2005). The current curriculum time allocated to chemistry in Kosovo has led to chemistry courses saturated with content in comparison to other natural science subject courses offered at lower and upper secondary schools. Not surprisingly, chemistry is becoming a less favoured subject among students. This dislike also limits the ability of teachers to do what they are being asked to do: to perform their principal objective of teaching future generations.

Science subject courses in Kosovo are taught as distinct, unrelated courses. As a result, a thorough analysis of the natural science curriculum in terms of content, time allocation and teaching sequence could have a huge impact on chemistry education. As indicated by Sheppard and Robbins (2005), in order to build a world-class science education system and training framework for the $21^{\text {st }}$ century, one has to rethink and reconsider, not only what chemistry content is taught, but also how chemistry is taught, when it is taught and how much curriculum time is dedicated to it.

\section{Conclusion}

The present article provides an overview of the chemistry education system, as well as chemistry teacher preparation, in Kosovo over the years. It aims to draw attention to science education in general, and particularly to chemistry education, the chemistry curriculum, chemistry teacher preparation and research.

Kosovo, the newest country in Europe, faces the prospect of joining the EU, which will open all sorts of opportunities and challenges for its population. These opportunities can be tapped into and the challenges overcome only with a well-established and resourceful education system in practice. Science education, particularly chemistry education, is an important component in the development process and needs considerable attention. Moreover, science education in Kosovo should fit the modern world while at the same time meeting the demanding developmental needs of Kosovo's population. Having the youngest population in Europe, Kosovo must restore, rebuild and practise 
a well-organised education system. This is an important step for Kosovo's development.

With the implementation of the Bologna Process in Kosovo, it is expected that universities, the overall education system, as well as future outcomes, will harmonise with European countries. Furthermore, it is expected that science education in Kosovo will take advantage of the opportunity to enhance teaching practices and student quality outcomes, and use the reform to overcome obstacles that have been part of a long-lasting process. In order to move forward, the Kosovo education system needs to close the gap in the professional development of teachers and student achievements, and to prepare a generation of university learners prepared for university studies and the labour market.

Education reform needs to improve the quality of education that will support economic development and help address inequalities. Particular attention should be paid to avoiding courses that produce knowledge that cannot be applied to real-world problems. Special focus should be given to fostering learning through facilitating, spending less time instructing and more time listening. Chemistry teacher education programmes need to provide teachers with knowledge and experience that foster the cultural significance of science, relating it to other subjects that apply multidisciplinary approaches to studying and solving problems.

The present article could be considered as a catalyst that stimulates the research community to focus on research on the chemistry curriculum and teacher development programmes, while analysing the pre-service and in-service teacher base CK and PCK and teacher education programmes, particularly chemistry education. However, such research alone will not bring meaningful changes if chemistry instruction in the classroom does not receive attention.

\section{References}

Bache, I., \& Taylor, A. (2003). The politics of policy resistance: reconstructing higher education in Kosovo. Journal of Public Policy, 23(3), 279-300.

Baliqi, B. (2010). Higher Education Policy in Kosovo - Its Reform Chances and Challenges. Der

Donauraum, 50(1), 43-62.

Berisha, F. (2013). Drinking Water Quality in Kosovo investigated by Inductively Coupled Plasma Mass Spectrometry and Science Education in Kosovo, Doctoral thesis. Graz, Austria: University of Graz. Bicaj, A., \& Berisha, F. (2013). Teacher Preparation Reforms in Kosovo. Journal of Education Culture and Society, 1, 199-208.

Bodner, G. M. (1992). Why changing the curriculum may not be enough? Journal of Chemical Education, 69(3), 186-190. 
Bucat, R. (2004). Pedagogical content knowledge as a way forward: applied research in chemistry education. Chemistry Education: Research and Practices, 5(3), 215-228.

Calik, M., \& Ayas, A. (2005). A comparison of level of understanding of eighth-grade students and science student teachers related to selected chemistry concepts. Journal of Research in Science Teaching, 42(6), 638-667.

Cheung, D. (2009). Students' attitudes toward chemistry lessons: The interaction effect between grade level and gender. Research in Science Education, 39, 75-91.

Cooper, M. M., \& Stowe, R. L. (2018). Chemistry education research - From personal empiricism to evidence, theory, and informed practice. Chemical Reviews, 118(12), 6053-6087.

De Jong, O. (2008). Context-based chemical education: how to improve it? Chemical Education International, 8(1), 1-7.

De Jong, O., Veal, W. R., \& Van Driel, J. H. (2002). Exploring chemistry teachers' knowledge base. In J. K. Gilbert, O. De Jong, R. Justi, D. F. Treagust, \& J. H. Van Driel (Eds.), Chemical Education: Towards Research-based Practice (pp. 369-390). Dordrecht: Springer. European Commission. (2004). Europe needs more scientists: Report by the high-level group on increasing human resources for science and technology. Brussels: European Commission. European Commission. (2010, November 9). Kosovo $\bigotimes_{2010}$ progress report accompanying the communication from the commission to the European Parliament and the council. Retrieved from https://ec.europa.eu/neighbourhood.../sec_1423_final_progress_report_ks_en.pdf European Commission. (2011, October 12). Kosovo®2011 progress report accompanying the communication from the commission to the European Parliament and the council. Retrieved from https://ec.europa.eu/neighbourhood-enlargement/sites/near/files/pdf/key_documents/2011/package/ ks_rapport_2011_en.pdf

European Commission. (2019, May 29). Commission Staff Working Document, Kosovo* 2019 Report. Retrieved from https://ec.europa.eu/neighbourhood-enlargement/sites/near/files/20190529-kosovoreport.pdf

European Commission. (2019). Reflection Paper "Towards Sustainable Europe by 2030". Brussels: European Commission.

European Commission/EACEA/Eurydice. (2013). Education and training in Europe 2020: Responses from the EU member states. Eurydice Report. Brussels: Eurydice. Retrieved from https://op.europa.eu/ en/publication-detail/-/publication/4cd55a97-854d-4fff-8ebd-3 $\mathrm{fd}_{3} \mathrm{f}_{3} 8 \mathrm{ca} 58 \mathrm{a}$

Haste, H. (2004). Science in my future: a study of values and beliefs in relation to science and technology amongst 11-21-year-olds. London, UK: Nestle Social Reseach Programme.

Holbrook, J. (2005). Making chemistry teaching relevant. Chemical Education International, 6(1), 1-12.

KEEN. (2019). Professional Development of Teachers in Kosovo. Prishtina: Kosovo Education and Employement Network, EU Project.

Kind, V. (2014). A degree is not enough: A quantitative study of aspects of pre-service science teachers' chemistry content knowledge. International Journal of Science Education, 36(8), 1313-1345. 
Mahaffy, P. (2004). The future shape of chemistry education. Chemistry Education: Research and Practice, 5(3), 229-245.

MEST. (2007). Strategy for development of Pre-University-Education in Kosovo (2007-2017). Prishtina: Ministry of Education, Science, and Technology (MEST).

MEST. (2016). Kosovo education strategic plan 2017 - 2021. Retrieved from http://www.kryeministriks.net/repository/docs/KOSOVO_EDUCATION_STRATEGIC_PLAN.pdf MEST. (2016a). Korniza Kurrikulare e Arsimit Parauniversitar të Republikës së Kosovës (e rishikuar) [Curriculum Framework of Pre-University Education of the Republic of Kosovo (revised)]. Retrieved from https://masht.rks-gov.net/uploads/2017/03/korniza-kurrikulare-finale.pdf MEST. (2016b). Kurrikula Bërthamë e arsimit të mesëm të ulët të Kosovës (klasa VI, VII, VIII dhe IX) (e rishikuar) [Core curriculum for lower secondary education in Kosovo (Grades VI, VII, VIII, and IX)]. Retrieved from https://masht.rks-gov.net/uploads/2017/03/korniza-berthame-2-final.pdf MEST. (2016c). Kurrikula Bërthamë për arsimin e mesëm të lartë të Kosovës (Gjimnazet - klasa X, XI, XII) (e rishikuar) [Core curriculum for upper secondary education in Kosovo (Gymnasiums - Grades X, XI, and XII)]. Retrieved from https://masht.rks-gov.net/uploads/2017/03/korniza-berthame-3-final.pdf OECD. (2006). Evolution of student interest in science and technology studies policy report. Paris: Organization for Economic Cooperation and Development.

OECD. (2016). Pisa 2015, Results in focus. Retrieved from https://www.oecd.org/pisa/pisa-2015results-in-focus.pdf

Osborne, J. (2007). Engaging young people with science: thoughts about the future direction of science education. In C. Linder, L. Ostman \& P. Wickman (Eds.), Promoting scientific literacy: science education research in transaction (pp. 105-112). Uppsala: Proceeding of Linnaeus Tercentenary Symposium held at Uppsala University.

Osborne, J., \& Dillon, J. (2008). Science education in Europe: Critical reflections (Vol. 13). London, UK: Nuffield Foundation.

Osborne, J., Simon, S., \& Collins, S. (2003). Attitudes towards science: A review of the literature and its implications. International Journal of Science Education, 25(9), 1049-1079.

Pinto, G. (2010). The Bologna process and its impact on university - level chemical education in Europe. Journal of Chemical Education, 87(11), 1176-1182.

Pupovci, D. (200o, November). Shifra dhe fakte mbi arsimin e Kosovoes [Figures and facts on Kosovo education]. Prishtine.

Pupovci, D. (2002). Teacher education system in Kosovo. Metodika, 3(5), 125-145.

Rocard, M., Csermely, P., Jorde, D., Lenzen, D., Walberg-Henriksson, H., \& Hemmo, V. (2007). Science education now: A renewed pedagogy for the future of Europe. Brussels: Directorate - General for Research, Science, Economy, and Society. European Commission.

Sheppard, K., \& Robbins, D. M. (2005). Chemistry, the central science? The history of the high school science sequence. Journal of Chemical Education, 83(4), 561-566.

Shulman, L. S. (1986). Those who understand: Knowledge growth in teaching. Educational Researcher, 15(2), 4-14. 
Shulman, L. S. (1987). Knowledge and teaching: Foundations of the new reform. Harvard Educational Review, 57(1), 1-23.

Sjoberg, S., \& Schreiner, C. (2005). How do learners in different cultures relate to science and technology? Asia-Pacific Forum on Science Learning, and Teaching, 6(2), 1-19.

Taber, K. S. (2017). Science Education. In K. S. Taber, \& B. Akpan (Eds.), Science education: An international course companion (pp. 3-19). The Netherlands: Springer.

UNDP. (2016). Making the labor market work for women and youth. Kosovo human development report 2016. Retrieved from http://hdr.undp.org/sites/default/files/human_development_report_2016.pdf Vula, E., \& Saqipi, B. (2009). Education in Kosova: Struggling between recovering and following modern trends. International Studies in Education, 10(1), 23-26.

Vula, E., Saqipi, B., Kraja, T., \& Mita, N. (2012). Moving towards Practice-Oriented and ResearchBased Teacher Education: Challenges of Kosovo and Albania. Excellence in Higher Education, 3(1), $37-45$.

\section{Biographical note}

FAtlume Berisha, $\mathrm{PhD}$, is an assistant professor in the field of science education at the Faculty of Education, University of Prishtina, Kosovo. Her main areas of research interest are in active teaching and learning of sciences, particularly chemistry education, STEM education, learning in makerspace labs, environmental education, and, more recently, education of science citizens of Kosovo, pre-service and in-service science teachers' beliefs, and science teacher professional development. 